\title{
Paideusis
}

\section{Justifying Bill 18: A Critique of Kymlicka's Comprehensive Neutrality}

Nick Tanchuk

Volume 22, Number 1, 2014

Sexual and Gender Diversity in Schools

URI: https://id.erudit.org/iderudit/1071469ar

DOI: https://doi.org/10.7202/1071469ar

See table of contents

Publisher(s)

Canadian Philosophy of Education Society

ISSN

0838-4517 (print)

1916-0348 (digital)

Explore this journal

Cite this article

Tanchuk, N. (2014). Justifying Bill 18: A Critique of Kymlicka's Comprehensive Neutrality. Paideusis, 22(1), 91-99. https://doi.org/10.7202/1071469ar
Article abstract

Manitoba's Bill 18 provides students the legal right to form gay-straight alliance student groups within denominational and dissentient schools. Religious opponents of Bill 18 claim that the law unjustifiably imposes a homogenous moral worldview on religious families. I argue that if we appeal to Will Kymlicka's comprehensive neutralist theory of political morality to justify Bill 18 , the religious complaint is problematically vindicated. I argue that Kymlicka appeals to two bases of neutrality that ultimately fail to distinguish his view from the perfectionist theories of political morality that he officially rejects. Due to this internal inconsistency, the priority of Kymlicka's preferred moral practices remains unjustified. For those of us who believe that Bill 18 is morally justified, an alternative approach to explaining this intuition is required.
This document is protected by copyright law. Use of the services of Erudit (including reproduction) is subject to its terms and conditions, which can be viewed online.

https://apropos.erudit.org/en/users/policy-on-use/ 


\title{
Justifying Bill 18: A Critique of Kymlicka's Comprehensive Neutrality
}

\section{NICK TANCHUK University of Manitoba}

\begin{abstract}
Manitoba's Bill 18 provides students the legal right to form gay-straight alliance student groups within denominational and dissentient schools. Religious opponents of Bill 18 claim that the law unjustifiably imposes a homogenous moral worldview on religious families. I argue that if we appeal to Will Kymlicka's comprehensive neutralist theory of political morality to justify Bill 18, the religious complaint is problematically vindicated. I argue that Kymlicka appeals to two bases of neutrality that ultimately fail to distinguish his view from the perfectionist theories of political morality that he officially rejects. Due to this internal inconsistency, the priority of Kymlicka's preferred moral practices remains unjustified. For those of us who believe that Bill 18 is morally justified, an alternative approach to explaining this intuition is required.
\end{abstract}

\section{Introduction}

Manitoba's Bill 18, "The Public Schools Amendment Act (Safe and Inclusive Schools)" provides students the legal right, inter alia, to set up gay-straight alliances in their schools. Supporters claim that Bill 18 includes students within an ideal of civic equality enshrined in Section 15 of the Canadian Charter of Rights and Freedoms. Opponents, by contrast, see Bill 18 as infringing on their religious freedom as it is expressed in the legal rights of denominational and dissentient schools. In this study, I consider an influential comprehensive neutralist theory of political morality advanced by Will Kymlicka as a possible means by which to assess the justification of conflicting rights claims within the public debate. Kymlicka endeavours to articulate a political morality that is neutral in its justification with respect to competing controversial conceptions of the good life. I argue that counter-examples undermine Kymlicka's categorical distinction between neutral and non-neutral forms of moral justification, problematically vindicating the objections of religious opponents. If we endeavour to justify the measures contained in Bill 18, I conclude that Kymlicka's comprehensive neutralist approach is inadequate.

\section{Justifying Manitoba's Bill 18: Civic Equality or Religious Freedom?}

Manitoba's Bill 18 “The Public Schools Amendment Act (Safe and Inclusive Schools)" extends the trend within Canadian criminal and constitutional law toward recognizing the legitimacy of LGBTQ identity. Under Bill 18, all students in Manitoba's publically-funded schools acquire the legal right to form student groups that promote "the awareness and understanding of, and respect for, people of all sexual orientations and gender identities" (Manitoba, 2012, ss 41(1.8)). Furthermore students are empowered to refer to such groups explicitly as "gay-straight alliances" (ss 41(1.8)). Such legal rights obtain even where a student attends a school

(C) Copyright 2014. The author, Nick Tanchuk, assigns to Paideusis the right of first publication and educational and non-profit institutions a non-exclusive license to use this document for personal use and in courses of instruction provided that the article is used in full and this copyright statement is reproduced. Any other usage is probibited without the express permission of the author. 
that was chosen by that student's parents precisely because it teaches religious beliefs that proscribe nonheterosexual practices. Nancy Allen, Manitoba's Minister of Education, has been clear: the provincial government's intention is that they are "not going to let faith-based schools opt out of providing a safe and caring environment for their students" (Kusch \& Martin, 2013).

Proponents of Bill 18 claim that the amendment to the Public Schools Act rightly includes LGBTQ students within an ideal of civic equality and provides important resources necessary to mitigate harms disproportionately shouldered by such students. Short (2013) argues, for example, that GSA laws include LGBTQ students within the egalitarian vision of Section 15 of the Canadian Charter of Rights and Freedoms (p. 330). Section 15 provides that all individuals ought to be treated as "equal before and under the law" and "to the equal protection and equal benefit of the law without discrimination" (Constitution Act, 1982, s 15(1)). Following Egan v Canada (1995), as Short rightly asserts, "without discrimination," is interpreted with respect to Section 15 as including sexual orientation within the list of illegitimate bases for differential treatment (2013, p. 330). Bill 18 extends this ideal of civic equality to students by demanding that they are not discriminated against on the basis of their sexual identity within any publically-funded school. Importantly, independent religious schools, many of which are morally opposed to homosexual practices, are among those that are publically funded. As a result, Bill 18 asserts the priority of civic equality even where parents may reject this effort due to conflicting moral and religious convictions. In so doing, the state, in Short's words, is "taking on God" (p. 327) with GSA laws such as Bill 18 — directly challenging the legal scope of parents' religious freedom with respect to their minor children-under the auspices of a normative conception of civic equality.

In addition, proponents of Bill 18 claim that GSA provisions can also be expected to reduce harms disproportionately experienced by LGBTQ students. The Manitoba Teachers' Society and the Rainbow Resource Center, for example, cite recent research involving 3,600 students across Canada, which found that $21 \%$ of LGBTQ students report being physically harassed or assaulted while $64 \%$ feel unsafe at schools, as evidence of such harms (Taylor and Peter, 2011, p. 16-17; Kusch and Martin, 2012). In light of such findings, proponents claim that Bill 18 can be interpreted as not only recognizing equality, but as also affirming students' constitutional rights "to life, liberty, and security of the person" and to "not to be subjected to any cruel and unusual treatment or punishment" (Constitution Act, 1982, s 1; s 7) The religious opponents of GSA laws concede the importance of this second point. Such opponents are willing to address issues of physical and emotional harm experienced by LGBTQ students provided that effort does not entail condoning same sex romantic relationships (Evangelical Fellowship of Canada [EFC], 2013, p. 17). To the extent that persons can both morally disapprove of and abstain from harming others, it is not a willingness to address harm that is in dispute between proponents and opponents of Bill 18 (EFC, 2013, p. 15).

Where proponents and opponents of Bill 18 disagree is regarding whether or not there is a moral obligation to support students in affirming homosexual identities within denominational and dissentient schools. Proponents assert and opponents deny this obligation. In the view of opponents, the extension of explicit legislative support for student-initiated GSAs wrongly entails overriding the Charter's right to freedom of religion and conscience, as this is expressed within the Section 29 rights of denominational and dissentient schools. In a position paper on Bill 18, the Evangelical Fellowship of Canada (2013) thus claims that:

The bill would set a new, lower standard in the province of Manitoba, for respect of its citizens' constitutional rights to religious and associational freedoms, as well as parental authority ... In the name of diversity and respect for others, Bill 18 proposes that the Government of Manitoba enforce select perspectives and belief systems, seeking to render the school system increasingly homogenous, rather than encouraging proper respect for each Manitoban child and the unique cultural and religiously informed perspective and up-bringing chosen for them by their parents. (p. 3)

The Evangelical Fellowship of Canada is not alone in their worries about religious freedom within schools. Leaders within the Sikh, Jewish, Muslim, and Coptic communities have publically expressed similar concerns about the curtailing of religious freedom implicit within Bill 18 (Canadian Press, 2013). Former Federal Public 
Safety Minister and constitutional lawyer Vic Toews, following this strand of dissent, has claimed that Bill 18's provisions "involve an unconstitutional infringement upon the freedom of religion" (EFC, 2013, p. 5)

In Canadian law there is at least some support for the type of concerns that motivate Bill 18's moral and religious opponents. Section 29 of the Charter explicitly rejects the extension of any provision within that act, including those of Section 15, to denominational and dissentient schools, where such an extension conflicts with the rights of those schools specified in the Constitution Act of 1867 (Constitution Act, 1982, RSC). The Constitution Act (1867), in turn, protects any rights such schools possessed "at the time of the Union" in 1867 (s 93(1)). Such 1867-based rights, moreover, have been held in recent cases to legally justify schools' denial of employment to teachers where they have violated religious teachings in their private life or on the basis of their conscientious non-adherence to a particular religious faith endorsed by a particular denominational school (Caldwell et al. v Stewart et al., 1984; Daly et al. v Ontario, 1999). The spirit of these constitutional provisions, which enshrine parents' legal right to cultivate a robust and distinct religious ethos within the lives of their minor children, serves to protect robust moral and religious pluralism. By restricting the involvement of the state within the private sphere of the family and parents' choice of education, believers in a diversity of genuinely incommensurable moral traditions are able to ensure that their manifold views survive inter-generationally and are not subsumed in a dominant majority's set of common values.

The religious opposition to Bill 18 is intelligible, even if it is not in the final analysis, defensible. Freedom of religion is a fundamental freedom under the Charter (s 2(a)). If our freedom to live by our conscience or religion is indeed a genuine negative right, detailing what the state will not interfere with, then one might reasonably think that under such a provision some deviation from official state norms is permissible. Failing the permissibility of such genuine moral plurality, it might appear that the officially asserted freedom from state interference in living by one's conscience or religion is just that of adhering to the state's official moral code. In this case, one might claim that such freedom is no real freedom of conscience or religion at all. By failing to respect the moral dissent of parents who claim an obligation intrinsic to their view of the good life to raise their children in accord with that view, the state, which officially recognizes freedom of conscience and religion, might appear at odds with itself. Ultimately, it may appear that, despite talk of pluralism and diversity, the state mandates that all children be raised to be liberal-egalitarian choosers of the good life first and foremost, and to not violate this singular and fundamental moral obligation in the name of any competing religious or conscientious view.

For the purposes of this essay, I will bracket the interesting legal questions regarding what Canadian courts in fact do, given the present positive law, with respect to constitutional rights claims. Instead, I focus on the philosophical question of what, if anything, the state or the court ought to do in such cases from the perspective of political morality. Adjudicating this normative philosophical question depends upon the facts regarding political morality - whatever they may be-and whether or not they afford any substantive normative truths that ought to guide conduct in such cases. A theory of political morality is relevant to Bill 18 on two fronts. First, if sound, such a theory will inform our understanding of the justifications we appeal to when we engage in public debate toward rendering legislative decisions. Second, if sound, a theory of political morality may ground our consideration of such decisions with students in the classroom.

\section{Does Kymlicka's Comprehensive Morality Justify Bill 18?}

Kymlicka's comprehensive neutralist liberal theory of political morality is one influential attempt to articulate the facts relevant to justifying state action against communal dissent. Kymlicka is perhaps the best and most careful exponent of such an approach against communitarian objections (Cf. Dagger 1999, p.188). So, if Kymlicka's account fails, a significant blow is landed against neutralist attempts to ground LGBTQ student rights, in general, and comprehensive neutralist approaches, specifically. By contrast, alternative approaches that are either non-neutral or non-comprehensive accrue prima-facie appeal, if Kymlicka's view is ruled out. I aspire to examine the possible advantages of such alternative approaches to grounding LGBTQ student rights in a forthcoming work. For now, I restrict myself to laying some of the necessary groundwork for that future project by critically appraising Kymlicka’s compelling approach. 
Kymlicka's argument for his theory of political morality consists of two steps. First, Kymlicka provides a normative philosophical anthropology, or comprehensive account of persons and their essential interests. Second, based on this anthropology, Kymlicka articulates a theory of our normative interest in a neutralist form of politics. Kymlicka's philosophical anthropology asserts two central premises: (1) that all persons have an essential interest in living a truly, as opposed to merely apparently, good life (Kymlicka, 1991, p. 10); and (2) that our lives only go well when we endorse the life we live "from the inside" (p. 13) without paternalistic interference. If this philosophical anthropology is true, then, Kymlicka claims, we require a politics that facilitates our capacities for critically reflecting upon and pursuing a wide array of conceptions of the good life, inasmuch as we may be wrong about which life is truly good (p. 13). Such a politics, in Kymlicka's view, is necessarily neutralist or anti-perfectionist.

According to Kymlicka, a perfectionist theory of political morality is one including "a particular view, or range of views, about what dispositions and attributes define human perfection and it views the development of these as our essential interest" (p. 33). Kymlicka's neutralist view, by contrast, rejects that we "are bound to any complex of interests" (p. 34). According to Kymlicka,

\begin{abstract}
...our essential interest in living a life that is in fact good requires an ability to revise our ends and to pursue those revised ends. Perfectionism inhibits this process. If we only have access to resources that are useful for one plan of life, then we shall be unable to act on our beliefs about value should we come to believe that that one preferred conception of the good life is misguided. (Or at any rate, we shall be unable to do so without suffering some penalization or discrimination in social benefits). (p. 34)
\end{abstract}

Kymlicka's anti-perfectionist or neutralist politics is instead grounded in a "thin theory of the good" (p. 34) that protects individual liberties and affords an egalitarian distribution of resources. Such a politics, based on a 'thin' rather than 'thick' theory, in Kymlicka's opinion, "best enables people to act on and examine their beliefs about value, and that is the most appropriate way to promote people's essential interest in leading a life that is in fact good" (p. 34).

If Kymlicka's comprehensive neutralist theory of political morality is sound, then the justification of state action for or against Bill 18 will not appeal to any controversial conception of the human good life. Kymlicka's approach, thus, may seem to parry the worry of religious groups who take the state to be unjustifiably imposing contested moral values on their children. On Kymlicka's view, the state does not aim to enforce "select perspectives and belief systems", but rather the background conditions for choosing any among a wide array of such perspectives or systems. Religious opponents of Bill 18, on this view, are simply mistaken. The state does not impose an "increasingly homogenous" moral vision, but rather the preconditions for a robust diversity of choices. On this view, religious opponents of Bill 18 are revealed as the real enemies of moral diversity, where they impose their view of the good life on their children through separate schools. Instead, on this view, parents who take diversity seriously ought to prioritize the development of their children's capacities for autonomous choice.

The religious opponents of Bill 18 would likely resist this claim. Instead, they might question the priority afforded to autonomous choice within Kymlicka's theory and how this priority itself escapes collapse into a form of the paternalistic perfectionism he officially rejects. To distinguish his politics of neutral concern as a normative rather than descriptive theory, Kymlicka sets his view in contrast with others that permit individuals to pursue conceptions of the good life that are at odds with our essential interest in the rational formation and revision of life plans (p. 56). Were there no possible or actual moral practices prohibited on Kymlicka's account, there would be no meaningful sense in which his view would be a normative account of political morality, as he intends. Given the necessity of such moral contrast cases, religious opponents might claim that it remains unclear how Kymlicka can escape conceding that his theory "includes a particular view, or range of views, about what dispositions and attributes define human perfection" (p. 33) and that "it views the development of these as our essential interest" (p. 33). If Kymlicka also imposes a perfectionist view on children, while denying this fact, his view is internally inconsistent and more work needs to be done to establish the priority of his preferred moral practices. 
Note that characteristically perfectionist views of politics such as those espoused by Aristotle or Hegel fail to specify, in full, what a perfect human being would look like or be. Instead, these views are perfectionist in the sense that they aim to provide a formal account of ends that the state ought to promote as good for all persons to realize within their otherwise different lives. On Kymlicka's view, the demand that the state promote a conception of persons as autonomous liberal-egalitarian choosers rather than as heteronomous illiberal choosers seems to encompass just this kind of perfectionism. In this regard, Kymlicka's liberalism meets the "particular view, or range of views" criterion he asserts is constitutive of perfectionist doctrines. Moreover, within Kymlicka's vision of liberal society, resources and sanctions are distributed such that they accord with the ideal of being an egalitarian liberal chooser of the good life_-just as is detailed on the second criterion of his definition of perfectionism. Those who interfere with the choosing of an autonomous agent, where the interference is clear-as in the most egregious cases of sexism, racism, religious hatred, and homophobia-in Kymlicka's opinion, justifiably face sanctions from the liberal state as a demand of political morality. Perpetrating individuals face such sanctions, moreover, regardless of the sincerity or resolve in the justice of their illiberal actions with respect to their conception of the good life-no matter how committed they are to endorsing their conception of the good life 'from the inside'. So, it seems that Kymlicka is committed to the view that some choices regarding the good life ought to be "penalized and discriminated against by society" (p. 33), his third criterion, for a doctrine's being perfectionist. In light of these facts, it might seem clear that the religious objection is sound; that Kymlicka's liberal political morality is an incoherent form of the perfectionism it officially rejects.

Kymlicka would likely concede that substantive moral judgments are promoted by the state on his liberal political morality, inasmuch as morality is judgmental by definition. Kymlicka would likely nevertheless deny that such moral judgments are perfectionist. To maintain this line of defense, Kymlicka requires a basis that distinguishes his normative commitments from both the moral scepticism and perfectionism that he rejects. Call such a basis a 'neutral maker'. Kymlicka appeals to two different neutral makers within his account: a normative view's (1) being non-controversial and (2) having wide relative scope. Both I will claim are inadequate.

Kymlicka invokes the first neutral maker in an argument he levies against Joseph Raz's liberal perfectionism. According to Raz, state action is by its nature engaged in controversial judgments regarding the good life (Raz, 1986, p. 162). So, in Raz's view, any coherent liberal justification will "invoke perfectionist ideals" (Kymlicka, 1991, p. 80). Kymlicka, however, argues that Raz is mistaken about liberalism being implicitly perfectionist because the liberal norms the latter defends are "non-controversial" (p. 81). According to Kymlicka, Raz's argument for liberalism's cultural norms is actually non-perfectionist inasmuch as it "relies on the non-controversial value of a secure cultural pluralism for people in developing their varying conceptions of the good" (p. 81). Due to the non-controversial grounding of the need for "secure cultural pluralism" as a means to develop a conception of the good life, Kymlicka maintains that Raz's insight "does not undermine the possibility of a politics of liberal neutrality" (p. 81). In Kymlicka's view, there is no reason why "governments couldn't develop a decision procedure for public support of the culture of freedom that respected the principle of neutral concern that was endorsable as fair by everyone in society" (p. 81). The state, in Kymlicka's view, could, for example, "ensure an adequate range of options, not by contributing to the ways that it finds valuable, but by providing tax incentives for private citizens to contribute to the ways of life they find valuable" (p. 81).

It should be evident that Kymlicka's appeal to a procedural solution, wherein everyone gets a say from their plural conceptions of the good life into the type of pluralism society will allow, is question begging in the debate about liberal neutrality with Raz. What is in dispute between perfectionists like Raz and Kymlicka is, inter alia, precisely the moral neutrality of such procedural solutions-where all individuals are provided equal say in the social outcomes society pursues. Raz is willing to acknowledge that such procedural pluralist solutions entail rejecting views of the good life that are morally opposed to exactly those solutions and, therefore, to acknowledge that the solutions in question depend upon perfectionist ideals. Kymlicka wants to deny this fact. Whether or not the attempted denial is ultimately possible, what is clear is that, on pain of circularity, Kymlicka cannot appeal to the possibility of such procedural solutions to establish those solutions' neutrality. 
The problem, then, for Kymlicka, is to explain how a view's being non-controversial establishes that the view in question is morally neutral, as this is what is left when the circular argument is subtracted from his account. Kymlicka does not provide a detailed examination of what it takes for a view to be controversial within his argument. He does, however, indicate a distinction between an empirical and a normative sense of the term 'controversial' in a footnote. Kymlicka appeals only to the latter of these two senses. So, I will only briefly consider the first empirical sense for completeness. On the first, empirical, usage of 'controversial' the degree to which a claim is controversial is defined by the degree of relevant empirical consensus or dissensus regarding that claim. To see that a normative commitment's being empirically non-controversial is insufficient on its own for a view's being non-perfectionist, we need only imagine a world in which a radically perfectionist doctrine is and has always been agreed to by a perfect consensus. If everyone agrees that a theocratic politics is correct, that does not transform the theocracy into an anti-perfectionist regime. This possibility is sufficient to reveal that a view's being empirically non-controversial is insufficient, on its own, for that view's being morally neutral in its justification.

The textual evidence suggests that Kymlicka would concede this point. According to Kymlicka, remarking on the meaning of 'non-controversial' he intends, "The point is not that diversity and complexity are valued equally in different conceptions of the good" (p. 97, note 4). Instead, Kymlicka employs the term 'controversial' in a different, less familiar, normative sense. On this normative usage of 'controversial', we might claim that one ought to realize or recognize that a particular claim is controversial or non-controversial upon due reflection. Think, here, of the rebel philosopher, calling her dogmatic community to recognize the actually controversial nature of their dogmatic moral consensus. We can perhaps equally imagine such a philosopher calling her community to recognize that some commitment, once we think about it correctly, is tacitly endorsed by all of us, and, thus, ought to be recognized as actually non-controversial despite our dogmatic claims of disagreement.

Kymlicka's remarks in a footnote to his argument against Raz's perfectionism indicate that it is in this normative sense that he takes liberalism's political morality to be non-controversial (p. 97, note 4). Quoting Dworkin directly, Kymlicka claims that

Since our intellectual environment provides the spectacles through which we identify experiences as valuable, it cannot sensibly be put on the scales as one of the experiences it identifies to be weighed against others and found more or less valuable than they. (Dworkin, 1985, p. 228)

Kymlicka concludes that, "The importance of cultural pluralism for a theory of liberal equality lies below, or prior to, the value attached to it in any of the particular conceptions which are contained in the culture" (p. 228). Recalcitrant others, on Kymlicka's view, are treated as though they ought to recognize the priority of the moral-epistemic process of evaluating diverse ends that he and Dworkin propose is of incommensurably higher importance than any conception of the good that might conflict with it. This fundamental interest in the process of rational normative evaluation, for Dworkin and Kymlicka, is to be taken as non-controversial only in the non-empirical sense that it is implicitly essential to our valuing projects and goals at all. So, undermining this process in the name of a valued project would be, in some sense, self-defeating; it would devalue precisely what we are doing in valuing some end or other.

Counter-examples, however, show that a view's being normatively non-controversial also fails to establish that the view in question is morally neutral rather than perfectionist. Consider the possibility of a perfectionist theocrat who rejects rationality as the means of forming and assessing moral views. Instead, the theocrat favours a non-rational faith-based moral epistemology_-say, of personal revelation through divine intervention. The theocrat, here by hypothesis, believes that God reveals moral truth to individuals in accord with his providential vision by intervening in history. Our rational, critical powers, in the theocrat's faithful view, do not reveal the truth about goodness, but, where this is claimed, reveal an imperfect form of human confusion. God's interceding agency, and not our own, reveals the truth about what is best in life.

Like Kymlicka, the perfectionist theocrat can claim that her faith-based moral epistemology and providential metaphysics ought to be recognized as non-controversial methods and preconditions of ascertaining moral truth. Obedient faith in the one true religion, revealed by providential intervention, rather 
than the rational judgment of its goodness, in her view, make up "the spectacles" through which we discover what is truly good for us as moral creatures. Perhaps she is wrong. Nevertheless, what is at issue in discerning who has the correct normative use of 'non-controversial' in such cases is simply which moral epistemology and metaphysics are true-hers or Kymlicka's. But if 'non-controversial' in this normative sense is equivalent to what one ought to recognize as morally, epistemically, and metaphysically true, this hardly distinguishes Kymlicka's anti-perfectionism from the perfectionism it endeavours to reject. Both sides can, and do, claim to be true moral views. It remains for Kymlicka to show why his view of moral truth is neutral, given its apparent congruence with his own definition of perfectionism, and its susceptibility to empirical controversy and dispute.

Here, Kymlicka might appeal to the second neutral maker mentioned within his account, a view's relative scope, to establish his view's moral neutrality. Kymlicka might claim that his theory's thinness-its wide relative scope with respect to competing conceptions of the good life-establishes its relative neutrality with respect to such doctrines. Thick views, like those of the religious opponents of Bill 18, Kymlicka might claim are relatively perfectionist insofar as they are consistent with a narrower array of moral practices. Thin views, like his and Dworkin's, Kymlicka might claim, are comparatively neutral. Notice that on this interpretation, 'neutral' becomes synonymous with 'permissive' with respect to some set of ends. A relatively permissive moral life, however, is consistent with perfectionism, provided the more permissive moral life is truly best. The permissive perfectionist will claim that the ends permitted or proscribed by her doctrine are selected to promote what is best for humanity, on her best theoretical account. Kymlicka as a neutralist, by contrast, must now face a dilemma.

Some views, such as utilitarianism, permit a wider array of moral practices than Kymlicka's comparatively thick view of the good, which rules some such conceptions out. If Kymlicka's moral framework is to be preferred over those that are more permissive than his own, it is either because his moral framework promotes a better life for humanity or it is not. If Kymlicka's moral framework is preferred because it promotes better forms of human life, then it is indistinguishable from a permissive form of perfectionist doctrine. If Kymlicka's moral framework does not promote a better life for humanity, then its priority over more permissive, more neutral views remains unclear. After all, if Kymlicka's preferred practices neither constitute a better form of human life nor are instrumental to a better form of human life, then what principled reason do we have to promote those ends for humans? Claiming that Kymlicka's preferred moral practices are not better, but 'right' or 'moral' simply begs the question against competing views of moral obligation and permissibility grounded in opposing principles or intuitions. In this latter case, we may promote Kymlicka's preferred morality as a matter of practice, or parochial predilection, but there is no rational normative justification for doing so. Nothing on either lemma establishes Kymlicka's view as neutral in aim.

Kymlicka does not note or appeal to any other sources of neutrality within his account and I cannot see any consistent with his view. Failing a property or range of properties that distinguish Kymlicka's view from perfectionist political moralities, the most theoretically simple explanation, by appeal to Leibniz' Law, is that his view is perfectionist. Like Bill 18's religious opponents, Kymlicka implicitly provides a substantive account of what it is good for a person to be, which sets the limits of obligatory and permissible behaviour, and grounds state sanctions and paternalistic guidance. Bracketing cultural and religious views that reject liberalism on the grounds that the former are 'controversial' or 'thick' incoherently elides the need to justify comprehensive liberalism's own perfecting vision of humanity with respect to such conceptions. Due to this internal coherence, the moral priority of Kymlicka's comprehensive neutralist view remains unsound as a basis for justifying state action with respect to students and families in the case of Bill 18.

Problematically, where we appeal to Kymlicka's comprehensive political morality to justify Bill 18, the worry of faith-based groups is vindicated. On Kymlicka's political morality, the EFC's claim that, unjustifiably, "In the name of diversity and respect for others, Bill 18 proposes that the Government of Manitoba enforce select perspectives and belief systems, seeking to render the school system increasingly homogenous," (p. 3) problematically, appears correct. Whatever we might think of the EFC's or any other religious group's positive doctrine, if we accept Kymlicka's neutralist view, Bill 18 does incoherently and therefore unjustifiably enforce select perspectives and belief systems, rendering our school system increasingly homogenous. If we 
wish to morally justify the practices enshrined in Bill 18 , as I believe we ought to, some alternative account is required.

\section{Conclusion}

To be clear, I believe that it is morally right to protect students' ability to form gay-straight alliances within their schools. I have argued, however, that Kymlicka's view fails to justify this practice on neutralist grounds. Failing an alternative account of neutrality, Kymlicka's political morality both denies and implicitly relies upon perfectionist considerations to ground its normative political commitments. His view is, therefore, internally incoherent. Importantly, this does not entail that the moral opponents of Bill 18 are morally justified in their

competing views. More work remains to be done before we can establish the most coherent theory of the moral landscape - whether it is some form of perfectionism, a moral-epistemically sceptical pragmatic view, or some better account of neutrality. On the basis of such work, we might acquire an adequate view from which to justify Bill 18's measures against religious dissent. For now, I have argued that a helpful first step in this regard is to notice that Kymlicka's comprehensive neutralist account is inadequate to the task.

\section{Acknowledgments}

The author thanks the Social Sciences and Humanities Research Council of Canada (SSHRC), the Province of Manitoba, and the University of Manitoba for funding that supported the development of this paper.

\section{References}

Caldwell et al. v. Stewart et al. (1984). 2 S.C.R. 603.

Canadian Press (2013, March 15). More religious leaders oppose Manitoba anti-bullying bill. CBC News. Retrieved July 20, 2013 from http://www.cbc.ca/news/canada/manitoba/more-religious-leadersoppose-manitoba-anti-bullying-bill-1.1324168

Constitution Act, Revised Statutes of Canada (1867). Retrieved from Department of Justice Canada website: http://laws-lois.justice.gc.ca/eng/Const/index.html

Constitution Act, Revised Statutes of Canada (1982). Retrieved from Department of Justice Canada website: http://laws-lois.justice.gc.ca/eng/Const/index.html

Dagger, R. (1999). The Sandelian Republic and the Unencumbered Self. The Review of Politics. 61(2), 181-208.

Daly v. Attorney General of Ontario. (1999). CLII 3715.

Dworkin, R. (1985). A matter of principle. Cambridge, MA: Harvard University Press.

Egan v. Canada, (1995). 2 S.C.R. 513.

Evangelical Fellowship of Canada. (2013). Falling short: Manitoba's Bill 18, The Safe and Inclusive Schools Act. Ottawa: Evangelical Fellowship of Canada Centre for Faith and Public Life.

Kusch, L., \& Martin, N. (2013, February 26). Opponents Bash Bullying Bylaw. The Winnipeg Free Press Retrieved from http://www.winnipegfreepress.com/local/opponents-bash-bullying-law193216981.html

Kymlicka, W. (1991). Liberalism, community, and culture. New York, NY: Oxford-Clarendon Press.

Manitoba, Bill 18: The Public Schools Amendment Act (Safe and Inclusive Schools). 2nd Sess., 40th Legislature, 2013, C.C.S.M. http://web2.gov.mb.ca/bills/40-2/pdf/b018.pdf

Raz, J. (1986). The morality of freedom. New York, NY: Oxford University Press. 
Short, D. (2013). Queering schools, GSAs and the law. In G. Walton (Ed.), The gay agenda: Claiming space, identity \& justice (pp. 1-13). New York, NY: Peter Lang.

Taylor, C., \& Peter, T. (2011). Every class in every school: The first national climate survey on homophobia, biphobia, and transphobia in Canadian schools. Egale Canada Human Rights Trust. Toronto, ON: Egale Canada Human Rights Trust.

\section{About the Author}

Nicolas J. Tanchuk is a graduate student in philosophy at the University of Manitoba. He can be reached at nick.tanchuk@gmail.com. 